\title{
Editorial
}

\section{Intelligent Materials for Solar Cells}

\author{
Surya Prakash Singh ${ }^{1}$ and Ashraful Islam ${ }^{2,3}$ \\ ${ }^{1}$ Inorganic \& Physical Chemical Chemistry Division, CSIR-Indian Institute of Chemical Technology, Hyderabad 500607, India \\ ${ }^{2}$ Photovoltaic Materials Unit, National Institute for Materials Science (NIMS), 1-2-1 Sengen, Ibaraki, Tsukuba 305-0047, Japan \\ ${ }^{3}$ Center of Excellence for Research in Engineering Materials (CEREM), College of Engineering, King Saud University, \\ Riyadh 11421, Saudi Arabia
}

Correspondence should be addressed to Surya Prakash Singh, singhspiict@gmail.com

Received 29 December 2011; Accepted 29 December 2011

Copyright (C) 2012 S. P. Singh and A. Islam. This is an open access article distributed under the Creative Commons Attribution License, which permits unrestricted use, distribution, and reproduction in any medium, provided the original work is properly cited.

Globally, the growth rate of the human population is increasing; therefore, there is a huge demand of energy to fulfill their requirements like vehicles, TVs, computers, ACs, and so forth. This causes global warming. Therefore, $\mathrm{CO}_{2}$-free energy is an emergent issue. In this context, solar energy is an alternate of fossil fuels. Dye-sensitized solar cells (DSSCs), organic thin-film solar cells, quantum dot solar cells, schottky solar cells, inorganic-organic heterojunction solar cells, and many others have been developed as an efficient, lowcost technology during the last years.

In dye-sensitized solar cells, the sensitizer is one of the key components for high power conversion efficiency. Among various organic/inorganic dyes, the most successful charge transfer sensitizers should be credited to black dye, N3 dye, and N719 dye. Dye-sensitized solar cells based on ruthenium complexes have broad absorption spectra extending into the near-IR region and produce solar-to-electrical energy conversion efficiencies of up to $11 \%$ under AM 1.5 irradiation. In order to improve the performance of solar cells, the sensitizer should absorb photons in the near-IR region as well as over the entire visible region of the solar spectrum, and longterm stability is another serious issue. To further improve the efficiency of dye-sensitized solar cells device, our main focus lies in the development of new sensitizers with a good spectral match with the solar emission.

This special issue contained high-quality research work addressing the latest innovations in nanomaterials research focused on solar cells, and synthetic nanomaterials considering the importance of light-harvesting materials in the design of novel generation of solar cells and smart nanomaterials.
We hope that this collection of papers will be a source of ideas and motivation for scientists across different fields in academia and industry to continue further research on organic solar cells.

\section{Acknowledgments}

The Guest Editors are very thankful to all authors that have contributed to this issue with high-quality papers. We are particularly indebted to the staff of Advances in Optoelectron$i c s$ for their professional and timely support.

Surya Prakash Singh Ashraful Islam 

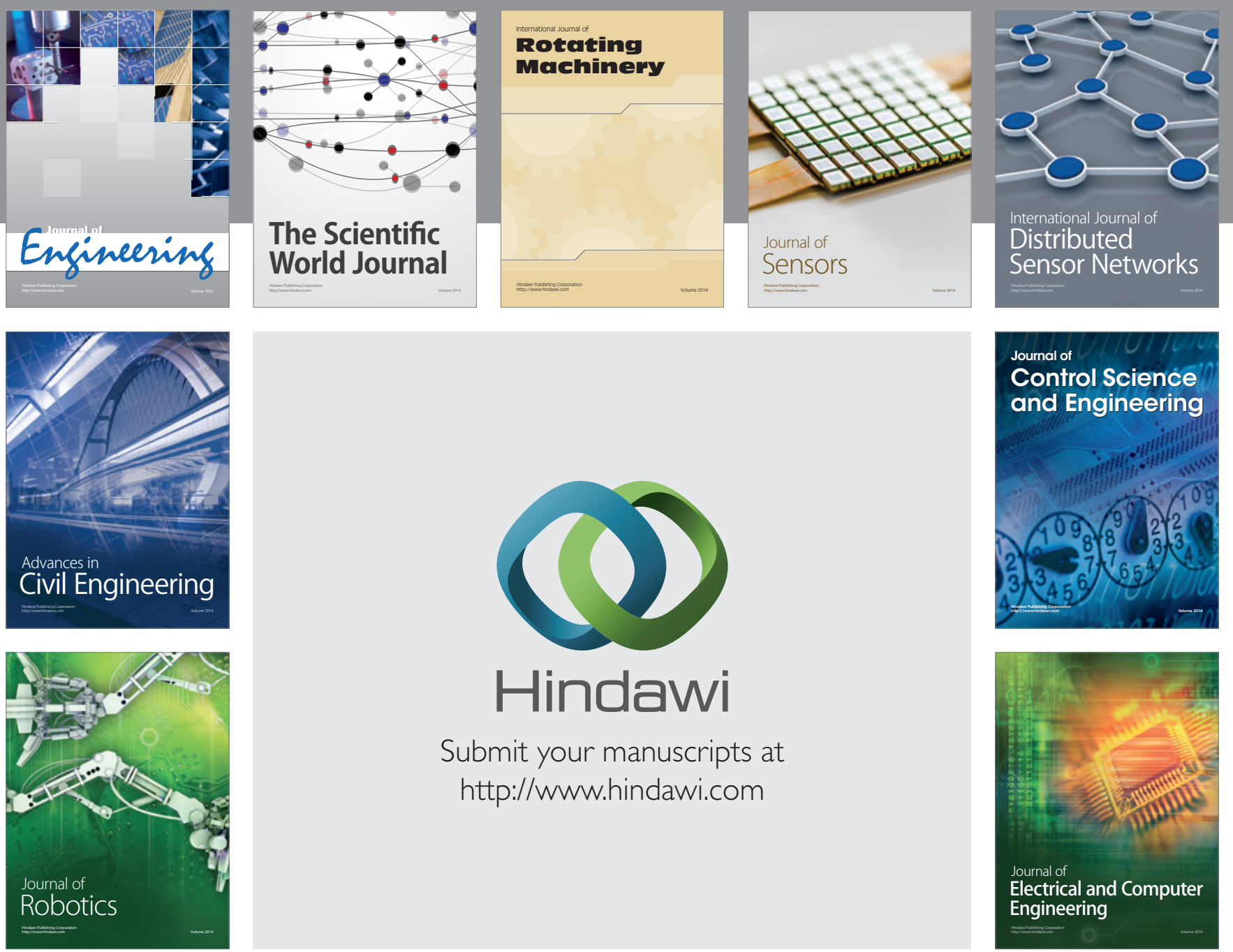

Submit your manuscripts at

http://www.hindawi.com
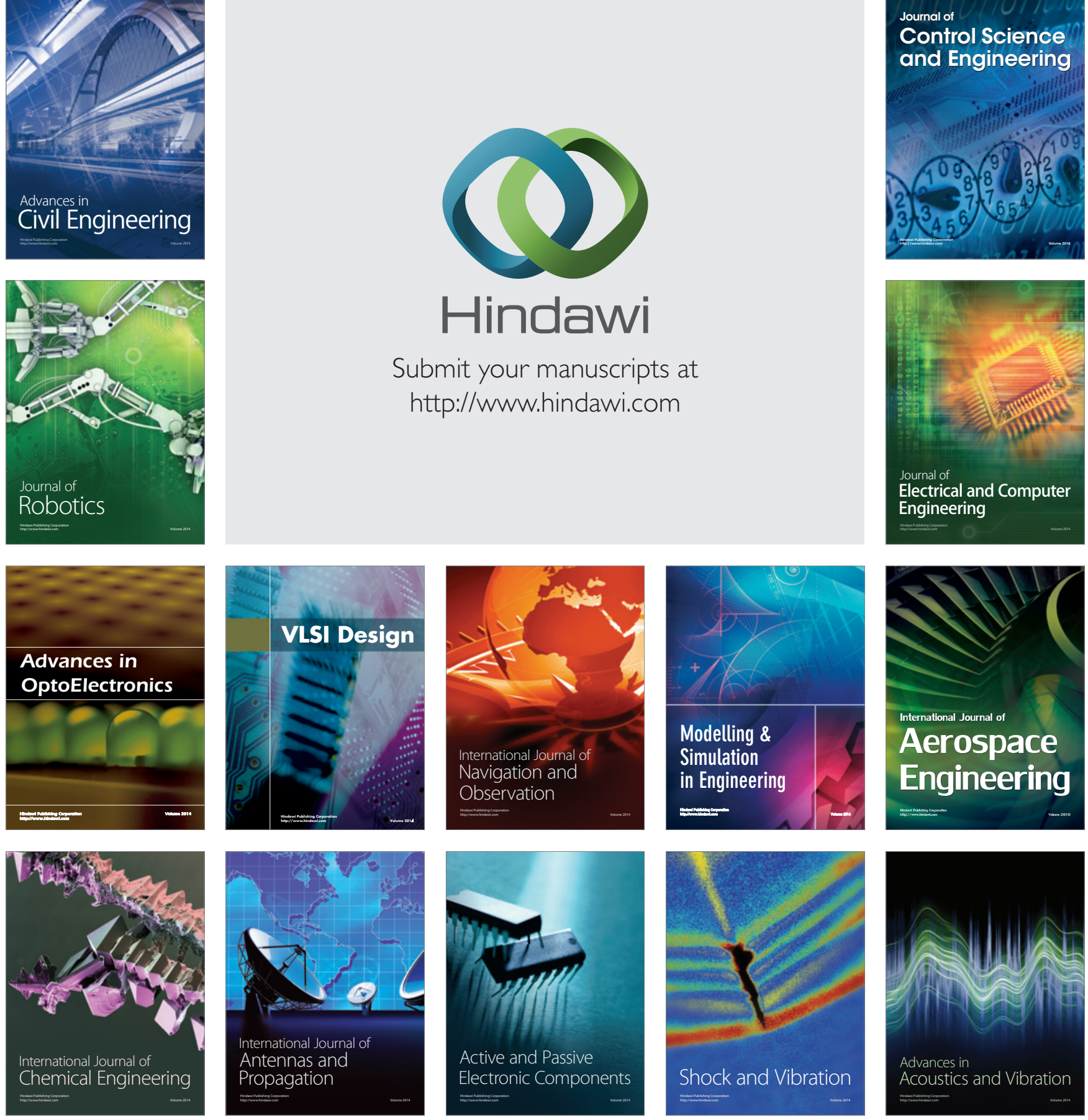